\title{
Serological Detection of Caseous Lymphadenitis in Sheep and Goats Using a Commercial ELISA in Grenada, West Indies
}

\author{
H. Hariharan ${ }^{1}$, K. P. Tiwari ${ }^{2}$, S. Kumthekar ${ }^{3}$, D. Thomas ${ }^{4}$, C. Hegamin-Younger ${ }^{5}$, B. \\ Edwards $^{6}$ and R. N. Sharma ${ }^{7}$ \\ ${ }^{1,2,3,6,7}$ Department of Pathobiology, School of Veterinary Medicine, P.O. Box 7, St. George's University, \\ St. George, Grenada, West Indies \\ ${ }^{4}$ Ministry of Agriculture, Forestry and Fisheries, St. George, Grenada, West Indies \\ ${ }^{5}$ Department of Preventive Medicine and Public Health, School of Medicine, St. George's University, St. \\ George, Grenada, West Indies
}

Correspondence should be addressed to H. Hariharan; hhariharan@sgu.edu

Received date: 22 May 2014; Accepted date: 30 August 2014; Published date: 5 October 2015

Academic Editor: Bhupendra Nath Tripathi

Copyright (C) 2015. H. Hariharan, K. P. Tiwari, S. Kumthekar, D. Thomas, C. Hegamin-Younger, B. Edwards and R. N. Sharma. Distributed under Creative Commons CC-BY 4.0

\begin{abstract}
Caseous lymphadenitis (CLA) in small ruminants has been diagnosed by culture several times in the state of Grenada. In order to understand the prevalence of CLA, serum samples from 541 sheep and 338 goats from Grenada and Carriacou islands were tested for antibodies against the phospholipase antigen of Corynebacterium pseudotuberculosis, the causative agent of caseous lymphadenitis (CLA) using a commercial ELISA kit: "ELITEST CLA". The percentage of positive samples among sheep was 7.9, and for goats it was $31.3 \%$, with a significant difference between these two species of animals. Of the six parishes of Grenada, and one parish of Carriacou, significantly more positive samples originated from St. George parish. There were no significant differences between age groups. The results of this study show that CLA is endemic and widely distributed throughout the islands of Grenada and Carriacou.
\end{abstract}

Key words: Caseous lymphadenitis, sheep, goats, ELISA, Grenada.

\section{Introduction}

Sheep and goats are important production animals in the state of Grenada, a tri-island nation in the Caribbean, due to their manageable size and feed requirements plus their ability to utilize sloped terrain and limited pasture areas. The rearing of sheep and goats for both meat and milk is

Cite this Article as: H. Hariharan , K. P. Tiwari , S. Kumthekar, D. Thomas , C. Hegamin-Younger , B. Edwards and R. N. Sharma (2015), " Serological Detection of Caseous Lymphadenitis in Sheep and Goats Using a Commercial ELISA in Grenada, West Indies ", International Journal of Veterinary Medicine: Research \& Reports, Vol. 2015 (2015), Article ID 473459, DOI: 10.5171/2015.473459 
increasing in Grenada (Annual Report, 2009). Grenada has an estimated small ruminant population of 3,000 sheep and 2,500 goats.

Caseous lymphadenitis (CLA) is a contagious and chronic disease of sheep and goats, caused by Corynebacterium pseudotuberculosis, a facultative intracellular bacterium. Abscesses, generally, involving subcutaneous lymph nodes are a common feature. Internal organs, especially lungs and internal lymph nodes can be affected. In both sheep and goats, production losses in weight gain, milk production, reproductive efficiency and carcass quality can occur (Powell, 2014). In a recent study in Canada on 152 goats, $3.9 \%$ of mortalities were attributed to CLA. Sporadic cases, including mastitis and occasional outbreaks in cattle, due to this organism have been reported (Shpigel et al., 1993). Nogradi and co-workers (2012) reported musculoskeletal $C$. pseudotuberculosis infection in 35 horses. $C$. pseudotuberculosis has zoonotic potential as well, and several cases of occupational infection, characterized by lymphadenitis, necessitating surgery, and antibiotic therapy, have been reported in humans handling infected animals, particularly, from Australia (Peel et al., 1997, Funke \& Bernard, 2011). In sheep and goats, CLA has been diagnosed by cultural methods many times in Grenada. Monitoring of disease status by culturing clinical samples will not help in control of this disease because of the fact that animals may be infected without showing obvious clinical signs. Treatment is generally ineffective, although one study showed that intralesional or systemic administration of tulathromycin may be an acceptable alternative to opening, draining, and flushing of CLA lesions (Washburn et al., 2009). Vaccines can be used to reduce the number of cases and severity of the disease (Windsor, 2014). However, control and eradication can only be achieved by identification of infected animals and removal from the herd. For this purpose, serological tests, including ELISA have been used (Sutherland et al., 1987). There are no published records of this disease in the Caribbean islands or West Indies, although it has been reported to occur in USA, Canada, Argentina, and Brazil (Williamson, 2001; Arsenault et al., 2003; Estevao Belchior et al., 2007; Guimaraes et al., 2011). Recently, an ELISA based on recombinant phospholipase D (PLD), a secreted protein from C. pseudotuberculosis has been developed, and marketed under the trade name "ELITEST CLA". As PLD is not known to be produced by any other sheep pathogenic bacteria, this ELISA is a very specific test (Hyphen Biomed com., 2014). This kit has been successfully used in Norway and Scotland for detection of CLA in small ruminants (Harkiss, 2014). The objective of this study was to generate data on prevalence of CLA in goats and sheep in Grenada by serological testing using "ELITEST CLA", so that control measures can be implemented.

\section{Materials and Methods}

Prior to the commencement of serological testing, the records of the Veterinary Diagnostic Bacteriology Laboratory, St. George's University, Grenada, were examined for reports of cases of CLA in sheep and goats from this country. In all cases, abscess contents were plated routinely on blood agar and MacConkey agar, and isolates suspected to be Corynebacterium pseudotuberculosis as described by Quinn et al. (1994) were confirmed by using Analytical Profile Index (API) Coryne strips. The growth on primary plating media was classified as "light", "moderate", and "heavy", and "pure" or "mixed". Three or less colonies of any morphological type were considered "insignificant". Corynebacterium pseudotuberculosis was isolated from 11 clinical cases of small ruminants in Grenada in the past. Of the 11 consecutive culturepositive samples, 10 were from goats, and one from sheep. Six positive samples were from females, and 5 from males. Abscesses were mostly (6/11) found to occur on neck or mandibular area. Internal abscesses were found in one animal, a sheep (Table 1). 
Table 1: Culture-positive Abscess content samples for Corynebacterium pseudotuberculosis from 11 small ruminants in Grenada (2004-2012)a

\begin{tabular}{|c|c|c|c|c|}
\hline $\begin{array}{c}\text { Year } \\
\text { sample } \\
\text { received }\end{array}$ & $\begin{array}{l}\text { Species and } \\
\text { number }\end{array}$ & Sex, Age & $\begin{array}{c}\text { Lesion/location of } \\
\text { abscess }\end{array}$ & $\begin{array}{c}\text { Culture } \\
\text { characteristics }\end{array}$ \\
\hline 2012 & Caprine (1) & M, "Adult" & $\begin{array}{c}\text { Abscess (2.5" firm), } \\
\text { lower neck }\end{array}$ & Heavy, pure growth \\
\hline 2012 & Caprine (1) & $\mathrm{F}, 3+$ years & $\begin{array}{c}\text { Abscess in caudal gluteal } \\
\text { muscles }\end{array}$ & Heavy, pure growth \\
\hline 2010 & Caprine (2) & F, “Adults” & Caseous abscesses $(\mathrm{NI})^{\mathrm{b}}$ & $\begin{array}{l}\text { Heavy, pure growth } \\
\text { from both animals }\end{array}$ \\
\hline 2010 & Ovine (1) & $\mathrm{F}, 5$ years & $\begin{array}{c}\text { Abscesses in liver, } \\
\text { pancreatic lymphnode }\end{array}$ & $\begin{array}{c}\text { Moderate, pure } \\
\text { growth from both } \\
\text { samples }\end{array}$ \\
\hline 2010 & Caprine (1) & M, 5 years & $\begin{array}{c}\text { Subcutaneous abscess in } \\
\text { mandibular region }\end{array}$ & $\begin{array}{l}\text { Moderate, pure } \\
\text { growth }\end{array}$ \\
\hline 2006 & Caprine (1) & M, "Adult" & Abscess on left mandible & $\begin{array}{l}\text { Moderate, pure } \\
\text { growth }\end{array}$ \\
\hline 2006 & Ovine (1) & M, "Adult" & Abscess (NI) & $\begin{array}{l}\text { Moderate, pure } \\
\text { growth }\end{array}$ \\
\hline 2004 & Goat (1) & F, 2-3 years & Neck abscess & $\begin{array}{l}\text { Moderate, pure } \\
\text { growth }\end{array}$ \\
\hline 2004 & Goat (1) & F, 2-3 years & $\begin{array}{c}\text { Neck abscess (6 cm in } \\
\text { diameter) with purulent } \\
\text { exudate }\end{array}$ & $\begin{array}{l}\text { Moderate, pure } \\
\text { growth }\end{array}$ \\
\hline 2004 & Goat (1) & $\begin{array}{l}\mathrm{M}, 2-3 \\
\text { years }\end{array}$ & Neck abscess & $\begin{array}{l}\text { Moderate, pure } \\
\text { growth }\end{array}$ \\
\hline
\end{tabular}

\section{a Unpublished information from the Veterinary Diagnostic Laboratory, St. George's University, Grenada \\ b NI: no information on location}

Serum samples from 541 sheep, and 338 goats $(16 \%$ of the total small ruminant population) from the islands of Grenada and Carriacou were obtained from clinically normal animals of at least 9 months of age. Animals were selected randomly from all 6 parishes of the island of Grenada, and from the island of Carriacou. The number of animals selected is in proportion to the number of small ruminants available in the particular parish/region.

"ELITEST CLA" (HYPHEN Biomed, neuville sur Oise, France) was used and interpreted according to manufacturer's instructions for serological detection of CLA. The test detected IgG antibodies specific for the conserved C. pseudotuberculosis virulence factor, phospholipase D. The test was performed at a room temperature of $20-25^{\circ} \mathrm{C}$ as per the recommended assay procedure. The cut-off values were calculated as per manufacturer's instructions.

\section{Results}

Of a total of 879 serum samples from sheep and goats tested, 149 (16.9\%) were positive for CLA. Compared to sheep, significantly more goats $(7.9 \%$ and $31.3 \%$ respectively) were positive for CLA (Table 2). There were significant differences in positive samples from parishes. St. George parish had the highest (43\%), and St. Andrews had the 
lowest (4\%) (Table 3). Age wise, sheep gave significantly lower positive results than goats in all age groups (Table 4). Age groups did not show significant differences in positivity.

Table 2: Sheep and goat samples positive for antibodies against CLA

\begin{tabular}{|l|l|l|l|}
\hline & Total tested & Numbers positive & Percentage positive (\%) \\
\hline Sheep & 541 & 43 & $7.9^{* *}$ \\
\hline Goats & 338 & 106 & 31.3 \\
\hline Total & 879 & 149 & 16.9 \\
\hline
\end{tabular}

Note: ** - statistically significant at the .001 level.

a There is a statistical significant difference between the proportion of sheep and goats testing positive for antibodies against CLA (chi-square=81.01, p-value $=<.001$ ).

Proportionately more goats tested positive.

Table 3: Parish/ region wise distribution of sheep and goat samples positive for antibodies against CLA ${ }^{\mathrm{a}}$

\begin{tabular}{|l|l|l|l|l|l|l|}
\hline Parish/Region & $\begin{array}{l}\text { Total } \\
\text { samples } \\
\text { of sheep } \\
\text { tested }\end{array}$ & $\begin{array}{l}\text { Number } \\
\text { of sheep } \\
\text { positive }\end{array}$ & $\begin{array}{l}\text { Percentage } \\
\text { of positive } \\
\text { sheep (\%) }\end{array}$ & $\begin{array}{l}\text { Total } \\
\text { samples } \\
\text { of goat } \\
\text { tested }\end{array}$ & $\begin{array}{l}\text { Number } \\
\text { of goats } \\
\text { positive }\end{array}$ & $\begin{array}{l}\text { Percentage } \\
\text { of positive } \\
\text { goats (\%) }\end{array}$ \\
\hline St. Andrews & 123 & 0 & 0 & 51 & 07 & 13.7 \\
\hline St. George & 13 & 02 & 15.3 & 82 & 39 & 47.5 \\
\hline St. David & 48 & 05 & 10.4 & 43 & 12 & 27.9 \\
\hline St. Mark & 39 & 03 & 7.6 & 14 & 0 & 0 \\
\hline St. John & 34 & 05 & 14.7 & 16 & 06 & 37.5 \\
\hline St. Patrick & 07 & 0 & 0 & 37 & 05 & 13.5 \\
\hline Carriacou & 277 & 28 & 10.1 & 95 & 37 & 38.9 \\
\hline Total & 541 & 43 & $7.9^{* *}$ & 338 & 106 & $31.3^{* *}$ \\
\hline
\end{tabular}

Note: **- statistically significant at the .001 level.

a There is a statistically significant difference in the proportion of sheep testing positive for antibodies against CLA by parish (chi-square $=31.01$, $p$-value $=<.001$ ). The highest parishes testing positive are St. George (15\%), St. John (14\%), St. David and Carriacou (10\% each). There is a statistically significant difference in the proportion of goats testing positive for antibodies against CLA by parish (chi-square=88.50, p-value $=<.001$ ). The parishes with the highest proportions are St. George (48\%), Carriacou (40\%), St. John (38\%) and St. David $(28 \%)$. 
Table 4: Age wise distribution of samples positive for antibodies against CLA ${ }^{a}$

\begin{tabular}{|l|c|c|c|c|c|c|}
\hline \multirow{2}{*}{ Age groups } & \multicolumn{3}{|c|}{ Sheep sample } & \multicolumn{3}{c|}{ Goats sample } \\
\cline { 2 - 7 } & Tested & Positive & $\begin{array}{l}\text { Percentage } \\
\text { (\%) }\end{array}$ & Tested & Positive & $\begin{array}{l}\text { Percentage } \\
\text { (\%) }\end{array}$ \\
\hline $\begin{array}{l}\text { 9 months-up to 2 } \\
\text { yrs }\end{array}$ & 139 & 11 & 7.90 & 80 & 25 & $31.25^{* *}$ \\
\hline 2 - up to 3 yrs & 176 & 14 & 7.95 & 67 & 21 & $31.34^{* *}$ \\
\hline 3 - up to 4 yrs & 25 & 02 & 8.00 & 89 & 28 & $31.46^{* *}$ \\
\hline 4 - up to 5 yrs & 201 & 16 & 7.96 & 102 & 32 & $31.37^{* *}$ \\
\hline
\end{tabular}

Note: $* *$ - indicates statistically significant at the .001 level

a Overall, sheep have significantly fewer positive than goats at each age group ( 9 months -2 years: chi-square $=20.13$, p-value $<.001 ; 2-3$ years: chi-square $=18.62$, $p$-value $<.001 ; 3-4$ years: chi-square=8.89, p-value $=.002$; and 4-5 years: chi-square $=27.82$, p-value $<.001$ ). No significant differences were seen between various age groups

\section{Discussion}

CLA is a chronic debilitating disease of global importance in sheep and goats, causing considerable economic losses due to culling of infected animals, carcass condemnation and decreased milk, wool production, reproductive efficiency, and mortality as well (Williamson, 2001; Debien et al., 2013). In the Americas, it occurs in Canada and USA (Debien et al., 2013, Powell, 2014). The prevalence of CLA in sheep in Quebec, Canada determined by presence of abscesses and positive culture was 21\% (Arsenault et al., 2003). Similar estimates in Australian sheep in 2009, was $12.9 \%$ for the province of Victoria (Windsor, 2014). Recent studies in a semi-arid tropical region of India showed a prevalence of $1.3 \%$ and $2.4 \%$, in sheep and goats, respectively by a specific PCR assay for C. pseudotuberculosis (Kumar et al. 2012, 2013). Serological tests for CLA have been described and developed further. Sutherland et al. (1987) described two enzyme-linked immunosorbent assays to measure antibody to the cell wall antigen and toxin antigen of $C$. pseudotuberculosis. Schreuder et al. (1994), used a double-antibody sandwich ELISA for eradication of CLA in two large flocks of sheep in which the disease was endemic. This ELISA was modified for use in sheep and goats, and it had a specificity of $\geq 98 \%$ for both species, and sensitivity of $94 \%$ for goats and $79 \%$ for sheep (Dercksen et al., 2000). Using this ELISA, $23 \%$ of small ruminants, mostly comprising of goats, in two districts of Malaysia, were found to be positive for CLA (Komala et al., 2008). Reboucas et al. (2011), described a modified ELISA for the detection of specific immunoglobulins against $C$. pseudotuberculosis secreted antigen. Using this assay, the seroprevalence of CLA in slaughtered sheep in the state of Minas Gerais, Brazil was estimated to be $43.7 \%$ (Guimaraes et al., 2011). The present study was possible because of the availability of a specific commercial immunoassay which was found useful in diagnosis of CLA in sheep and goats in Scotland and Norway, respectively (Hyphen biomed, 2014). Among sheep and goats in the present study, proportionately more goats tested positive for CLA, with a statistically significant difference. The reasons for the higher prevalence in goats are unknown. It is notable that 10 of 11 culture-positive samples in our diagnostic laboratory originated from goats (Personal communication, 2014). Among parishes, St. George showed the highest seroprevalence of CLA. The reasons are not understood, and needs further investigation. However, the data should be cautiously interpreted, because of the fact that number of samples collected from parishes varied. Further, 
farming is not organized in Grenada, and it is practically impossible to correlate differences in prevalence to animal husbandry conditions and environmental or other factors. It is hoped that the data generated in this study can be of help in designing future investigations. It is obvious that CLA is endemic in Grenada, and possibility of vaccination need to be considered in view of the fact that the herds are small, and culling all positive animals may not be practicable. The current study provides a baseline for continued screening of this disease in small ruminants in Grenada and other Caribbean islands.

\section{Acknowledgements}

The authors would like to thank V. MatthewBelmar, E. Brathwaite, J. Coughlin, Z. Pearl, B. Read, and G. Roy for technical assistance.

\section{References}

1. Annual Report. (2009). Ministry of Agriculture, Forestry and Fisheries, Grenada - Annual Report, 2009.

2. Arsenault, J., Girard, C., Dubreuil, P., Daignault, D., Galarneau, J.R., Boisclair, J., Simard, C. \& Belanger, D. (2003). "Prevalence of and carcass condemnation from maedivisna, paratuberculosis and caseous lymphadenitis in culled sheep from Quebec, Canada," Preventive Veterinary Medicine, 59:67-81.

3. Debien, E., Helie, P., Buczinski, S., Leboeuf, A., Belanger, D. \& Drolet, R. (2013). "Proportional mortality: A study of 152 goats submitted for necropsy from 13 goat herds in Quebec, with a special focus on caseous lymphadenitis," Canadian Veterinary Journal, 54:581-587.

4. Dercksen, D.P., Brinkhof, J.M., DekkerNooren, T., Maanen, K., Bode, C.F., Baird, G. \& Kamp, E.M. (2000). "A comparison of four serological tests for the diagnosis of caseous lymphadenitis in sheep and goats," Veterinary Microbiology, 31: 167-175.
5. Estevao Belchior, S., Gallardo, A., Abalos, A., Diaz, Y., Alvarez, L., Callejo, R., Prieto, M., Jodor, N. \& Jensen, O. (2007). Diagnosis of caseous lymphadenitis in sheep from Patagonia. Revista Argentina de Microbiologia 39: 44-46.

6. Funke, G. \& Bernard, K. A. (2011). “Coryneform Gram-Positive Rods" In: Manual of Clinical Microbiology, $10^{\text {th }}$ edition. Versalovic, J., Carroll, K.C., Funke, G., Jorgensen, J.H., Landry, M.L. \& Warnock, D.W (Editors). pp. 413-442. ASM Press, Washington, DC.

7. Guimaraes, A.S., Carmo, F.B., Heinemann, M.B., Portela, R.W., Meyer, R., Lage, A.P., Sdyffert, N., Miyoshi, A., Azevedo, V. \& Gouveia, A.M. (2011). "High sero-prevalence of caseous lymphadenitis identified in slaughter samples as a consequence of deficiencies in sheep farm management in the state of Minas Gerais, Brazil," $B M C$ Veterinary Research 2011. 7:68.

8. Harkiss, G. (2014). www.mvdiagnostics.co.uk. Accessed 14 May, 2014.

9. Hyphen Biomed. (2014). www.hyphenbiomed.com. Accessed 14 May, 2014.

10. Komala, T.S., Ramlan, M., Yeoh, N.N., Surayani, A.R. \& Sharifah Hamidah, S.M. (2008). "A survey of caseous lymphadenitis in small ruminant farms from two districts in Perak, Malaysia - Kinta and Hilir Perak," Tropical Biomedicine, 25:196-201.

11. Kumar, J., Singh, F., Tripathi, B.N., Kumar, R. \& Dixit, S.K. (2012). "Epidemiological, bacteriological and molecular studies on caseous lymphadenitis in Sirohi goats of Rajasthan, India," Tropical Animal Health and Production, 44:1319-1322.

12. Kumar, J., Tripathi, B.N., Sonawane, G.G. \& Dixit, S.K. (2013). "Rapid detection of Corynebacterium pseudotuberculosis in 
clinical samples from sheep," Tropical Animal Health and Production, 45:1429-1435.

13. Nogradi, N., Spier, S.J., Toth, B. \& Vaughan, B. (2012). "Musculoskeletal Corynebacterium pseudotuberculosis infection in horses: 35 cases (1999-2009)," Journal of American Veterinary Medical Association, 241:771-777.

14. Peel, M.M., Palmer, G.G., Stacpoole, A.M. \& Kerr, T.G. (1997). "Human lymphadenitis due to Corynebacterium pseudotuberculosis: Report of ten cases from Australia and Review," Clinical Infectious Diseases, 24:185191.

15. Personal communication. (2014). Veterinary Diagnostic Laboratory, St. George's University, Grenada, West Indies.

16. Powell, J. (2014). "Caseous Lymphadenitis in Small Ruminants," University of Arkansas Publication FSA3095. http://www.uaex.edu/publications/pdf/FSA -3095.pdf

17. Quinn, P.J., Carter, M.E., Markey, B. \& Carter, G.R. (1994). Clinical Veterinary Microbiology, Wolfe/Mosby Publishing, London, England. pp. 137-143.

18. Reboucas, M.F., Portela, R.W., Lima, D.D., Loueiro, D., Bastos, B.L., Moura-Costa, L.F., Vale, V.L., Miyoshi, A., Azevedo, V. \& Meyer, R. (2011). "Corynebacterium pseudotuberculosis secreted antigen-induced specific gammainterferon production by peripheral blood leukocytes: Potential diagnostic marker for caseous lymphadenitis in sheep and goats," Journal of Veterinary Diagnostic Investigation, 23:213-220.
19. Schreuder, B.E., Ter, L.E.A. \& Dercksen, D.P. (1994). "Eradication of caseous lymphadenitis in sheep with the help of a newly developed ELISA technique," Veterinary Record, 135:174-176.

20. Shpigel, N.Y., Elad, D., Yeruham, I., Winkler, M. \& Saran, A. (1993). "An outbreak of Corynebacterium pseudotuberculosis infection in an Israeli dairy herd," Veterinary Record, 133:89-94.

21. Sutherland, S.S., Ellis, T.M., Mercy, A.R., Paton, M.W. \& Middleton, H. (1987). "Evaluation of an enzyme-linked immunosorbent assay for the detection of Corynebacterium pseudotuberculosis infection in sheep," Australian Veterinary Journal, 64:263-266.

22. Washburn, K.E., Bissett, W.T., Fajt, V.R., Libal, M.C., Fosgate, G.T., Miga, J.A \& Rockey, K.M. (2009). "Comparison of three treatment regimens for sheep and goats with caseous lymphadenitis," Journal of American Veterinary Medical Association, 234:11621166.

23. Williamson, L.H. (2001). "Caseous lymphadenitis in small ruminants," Veterinary Clinics of North America - Food Animal Practice, 17:359-371.

24. Windsor, P.A. (2014). "Managing control programs for ovine caseous lymphadenitis and paratuberculosis in Australia, and the need for persistent vaccination," Veterinary Medicine: Research and Reports, 2014, 5:1122. 